\title{
PENINGKATAN KAPASITAS APARATUR PEMERINTAHAN DI DESA SEPABATU KECAMATAN TINAMBUNG KABUPATEN POLEWALI MANDAR
}

\section{ENHANCEMENT OF THE CAPACITY OF THE APPARATOR GOVERNMENT IN SEPABATU VILLAGE KECAMATAN TINAMBUNG POLEWALI MANDAR DISTRICT}

\author{
Akbar Indrawan Saudi ${ }^{*}$, Taufik Hidayat B. ${ }^{2}$, Riadi Ibnu Khaldun ${ }^{3}$ \\ ${ }^{1}$ (Sipil, Fakultas Teknik, Universitas Sulawesi Barat, Indonesia); ${ }^{2}$ (Akuntansi, Fakultas Ekonomi, Universitas \\ Sulawesi Barat, Indonesia); ${ }^{3}$ (Hukum Internasional, Fakultas Ilmu Sosial dan Politik, Universitas Sulawesi \\ Barat, Indonesia) \\ lakbarindrawan@unsulbar.com
}

\begin{abstract}
Abstrak
Pemerintahan Desa sebagai bagian dari suatu sistem sosial memiliki peran penting dalam pengelolaan masyarakat khusunya dalam aspek sosial bermasyarakat. Dalam melaksanakan penyelenggaraan pemerintahan di desa, pemerintahan desa, kelembagaan, pemahaman keuangan desa yang tertib dan infrastruktur desa tersebut diperlukan aparatur pemerintah desa dan masyarakat yang mampu dan memiliki kapasitas. Permasalahan yang ditemukan di Desa Sepabatu adalah masih rendahnya kemampuan aparatur pemerintahan desa dalam stuktur kelembagaan yang belum memiliki beberapa komponen lembaga pemberdaya desa seperti karang taruna dan lembaga perhimpunan pemuda desa. Permasalahan selanjutnya ialah struktur pengelolaan keuangan desa yang masih lambat dan tidak tepat waktu. Selain keuangan, permasalahan lainya ialah manajemen pelayanan desa dan minimnya kemampuan tenaga pengelola keuangan desa sehingga menghambat proses keuangan. Dari segi infrastuktur di Desa Sepabatu masih rendahnya pemahaman tentang manajemen infrastuktur yang menghubungkan ke tempat-tempat sumber ekonomi. Metode teknik yang digunakan adalah pendidikan masyarakat dengan menggunakan pendekatan Participatory Rural Appraisal (PRA) diantaranya metode pelatihan (training), demonstrasi percobaan, dan pembinaan terhadap aparat desa. Hasil evaluasi memperlihatkan rata-rata perubahan kemampuan dan pengetahuan aparatur desa sebesar 34,33\%. Dengan nilai tingkat kepuasan selama mengikuti kegiatan sebesar 30-40\% merasakan sangat puas dengan program ini.
\end{abstract}

Kata Kunci: Pemerintahan, Aparatur, Administrasi, Keuangan, Infrastruktur

\begin{abstract}
Village government as part of a social system has an important role in community management, especially in the social aspect. In implementing governance at the village, the village administration, kel e mbagaan, financial literacy orderly village and village infrasktur is needed of government personnel villages and communities that are able and have the capacity. The problem in Sepabatu village is still the low capacity of village government officials in the institutional structure with the absence of several components of village empowerment institutions such as youth organizations and village youth association institutions. The next problem is that the village financial management structure is still slow and not on time. Apart from financial, other problems are the management of village services and the lack of capacity of village financial managers, which hinders the financial process. In terms of infrastructure in Sepabatu Village, there is still a lack of understanding of the management of infrastructure that connects to places of economic resources. The technical method used is community education using the Participatory Rural Appraisal (PRA) approach including training methods, experimental demonstrations, and coaching village officials. The evaluation results showed that the average change in the ability and knowledge of village officials was $34.33 \%$. With the value of the level of satisfaction during participating in the activity of 30-40\% feel very satisfied with this program.
\end{abstract}

Keywords: government, apparatus, administration, finance, infrastructure 


\section{PENDAHULUAN}

Pemerintah Desa selaku pelaksana terdepan dalam menyediakan pelayanan kepada masyarakat sangat berkaitan dengan peraturan perundang-undangan. Konsep penerapan $e$ government dalam tata kelola pemerintahan menjadi penting terutama terkait penerapan aplikasi teknologi informasi (Taufiq et al., 2019). Model penguatan kapasitas pemerintah desa dalam menjalankan fungsi pemerintahan berbasis Electronic Government menuju pembangunan desa berdaya saing oleh (Salahudin, 2016) menemukan bahwa meskipun pemerintah desa mampu menjalankan penyelenggaraan pemerintahan desa dengan baik namun pemerintah desa menghadapi masalah serius dalam proses penyelenggaraan yaitu minimnya kapasitas sumber daya manusia pemerintah desa, jumlah perangkat desa yang terbatas, dan perangkat desa belum memahami tugas pokok dan fungsinya masing-masing.

Penelitian (Nugroho et al., 2016) menghasilkan, kebijakan pemerintah menetapkan arah pengelolaan pemerintahan menuju tata kelola pemerintahan yang baik (good governance) dan reformasi birokrasi alam upaya mewujudkan aparatur desa yang mampu melaksanakan pemerintahan yang baik sesuai prinsip-prinsip good governance. Salah satu caranya yaitu melakukan berbagai pelatihan yang didukung dengan perbaikan dan peningkatan modul pelatihan serta pemantapan materi melalui studi lapang. Dalam melaksanakan tata kelola pemerintahan yang baik di desa perlu difokuskan pada penyelenggaraan pemerintahan desa, kelembagaan, manajemen aset infrastruktur dan pemahaman keuangan desa yang tertib serta sesuai aturan yang berlaku. Sehingga diperlukan aparatur pemerintahan desa dan masyarakat yang mampu dan memiliki kapasitas untuk menjalakan hal tersebut.

Salah satu konteks yang berperan penting dalam kemajuan perkembangan desa yaitu pemanfaatan penggunaan dana desa. Menurut Syafingi et al., (2018) memperlihatkan bahwa paradigma Undang-Undang yang dianut oleh pemerintah desa dalam memahami ketentuan tentang penggunaan dana desa untuk kegiatan pemberdayaan masyarakat telah melahirkan jenis-jenis kegiatan pemberdayaan yang limitatif pada kegiatan pelatihan, kegiatan keagamaan, bantuan keuangan dan penyertaan modal. Peraturan Undang-Undang nomor 6 tahun 2014 dalam pengelolaan keuangan diharapkan mampu menjadikan desa lebih transparansi dan akuntabel. Hambatan dalam pelaksanaan good governance pengelolaan keuangan desa yaitu sumber daya manusia yang ada di pemerintahan desa yang tidak cakap (Astuti dan Yulianto, 2016). Pemanfaatan anggaran dana desa dapat dilakukan melalui 
program kewirausahaan masyarakat dengan komoditas unggulan lokal dapat menjadi solusi dalam pemanfaat dana desa, seperti kegiatan pendampingan dan pelatihan kewirausahaan masyarakat nelayan oleh di Kampung Tua Tanjung Gundap kelurahan Tembesi Kecamatan Sagulung kota Batam (Zamora dan Nurhayati, 2019).

Dalam penelitian lain (Sulandra dan Mudarya, 2018), kemampuan aparat desa dalam pelaksanaan tugas administrasi pemerintahan desa kurang efektif, dan kepatuhan atau kedisipilinan kerja aparat desa dalam pelaksanaan administrasi desa masih rendah. Faktor pendukung adalah adanya peraturan tentang administrasi desa dan penghambat pelaksanaan tugas administrasi pemerintahan desa. Studi kasus yang dilakukan oleh Hasibuan et al., (2020) dalam melakukan pendampingan aparatur pemerintah terkait pelaksanaan tugas Administrasi Kependudukan (KTP) di Wilayah Pulau Abang mampu menghasilkan peningkatan tugas pokok dalam pencatatan kependudukan secara efisien dan efektif.

Permasalahan yang terjadi dalam penyelenggaraan peningkatan kapasitas aparatur desa menurut Sidik (2017) yaitu aparatur desa yang belum mampu menangani beberapa urusan kewenangan pemerintah desa. Belum optimalnya pembinaan jaringan komunikasi antar aparatur desa dan penyelenggaraan pemberdayaan yang tidak dilakukan secara rutin. Apabila pemberdayaan dipahami sebagai strategi pembangunan maka jenis-jenis kegiatan pemberdayaan akan lebih variatif dan dapat menjangkau berbagai kegiatan yang selama ini dimasukan dalam bidang pembangunan. Faktor belum maksimalnya aparatur desa adalah ketidakefektifan pembagian peran kerja serta tugas, kemudian masalah disiplin kerja, pendidikan dan pelatihan, sarana dan prasarana dan tingkat kesejahteraan aparatur pemerintah desa (Arsjad, 2018).

Dalam data Kementerian Desa, Pembangunan Daerah Tertinggal dan Transmigrasi yang tercantum melalui Pusat Data Desa Indonesia, menyatakan Desa Sepabatu tergolong dalam Kategori Tertinggal menurut Indeks Desa Membangun dengan nilai 0,595 Tahun 2019 dan tergolong Berkembang menurut Indeks Pembangunan Desa dengan nilai 69,925 Tahun 2018. Terdapat 546 keluarga, Kepala Desa, Sekretaris Desa, 12 Aparatur Pemerintahan dan 7 Anggota BPD/Lembaga Masyarakat. Tingkat pendidikan masyarakat rata-rata lulusan SMP dan SMA yang berkorelasi dengan mata pencaharian utama masyarakat sebagai pekerja berpenghasilan tidak tetap (Badan Pusat Statistik, 2020). Oleh sebab itu, peningkatan kapasitas aparatur desa dalam tata kelola administrasi pemerintahan desa menjadi hal yang 
sangat penting. Dalam hal ini, upaya bagi aparatur pemerintahan desa untuk mengikuti pelatihan administrasi pemerintahan desa perlu diwujudkan. Tujuan dari kegiatan pengabdian masyarakat ini adalah memberikan pelatihan tentang kelembagaan desa, pengelolaan dana desa, manajemen infrastuktur, manajemen aset desa dan tata kelola pelaporan keuangan desa dalam rangka meningkatkan kapasitas aparatur pemerintahan Desa.

\section{METODOLOGI}

Metode pengabdian yang dilaksanakan yaitu bentuk pendampingan dan pelatihan menjadi media dalam menyalurkan pengetahuan dan keterampilan dalam aktivitas pengelolaan dan manajemen permasalahan mitra. Maka dalam penyelenggaraan program dilakukan dengan metode sosialisasi, diskusi dan tanya jawab, pendampingan serta pelatihan teknis dan tes tertulis. Untuk mencapai tujuan program maka dalam pelaksanaannya, teknik yang digunakan adalah pendidikan masyarakat dengan menggunakan pendekatan Participatory Rural Appraisal (PRA) diantaranya metode pelatihan (training), demonstrasi percobaan, dan pembinaan terhadap aparatur pemerintah Desa. Kegiatan dilangsungkan dalam waktu 7 hari dengan peserta sebanyak 25 orang dari aparatur dan perwakilan masyarakat.

Kegiatan penguatan aparatur pemerintah desa yang dilakukan dalam kegiatan pengabdian masyarakat merujuk kepada beberapa sasaran yaitu Penguatan Kelembagaaan Desa, Peningkatan Proses Pengelolaan Dana Desa, Peningkatan Pengelolaan Infrastruktur Desa, Manajemen Pengelolaan Desa dan Aset, dan Tata Kelola Keuangan sesuai PerundangUndangan. Melalui perumusan sasaran ini, diharapkan akan memberikan peningkatan kinerja aparatur pemerintah desa dalam proses menjalankan sistem tata pemerintahan desa yang baik dan benar serta dapat mencapai tujuan menjadi desa yang mandiri, unggul dan berkemajuan teknologi. Pendekatan dalam masalah mitra dan solusi yang menjadi fokus pada pelaksanaan kegiatan ini dapat dilihat melalui Figur 1.

Pembinaan secara berkelanjutan di lapangan, dan memonitoring untuk mengetahui pemahaman aparat desa terhadap kegiatan yang telah dilaksanakan. Hasil monitoring dijadikan sebagai bahan evaluasi untuk kemudian ditindaklanjuti terhadap kebijakan selanjutnya. Terdapat rancangan evaluasi yang akan digunakan untuk kegiatan ini dengan penjabaran sebagai berikut, yaitu Evaluasi secara kualitatif dilakukan melalui diskusi atau 
tanya jawab dengan pemantauan selama proses penyuluhan dan sosialisasi terhadap materi yang disajikan selama proses penyuluhan dan sosialisasi berlangsung antara penyaji materi dengan peserta sosialisasi, khususnya yang terkait dengan aspek yang berhubungan dengan pengelolaan keuangan Desa Kelembagaan Desa, dan Manajemen Infrastruktur Desa.

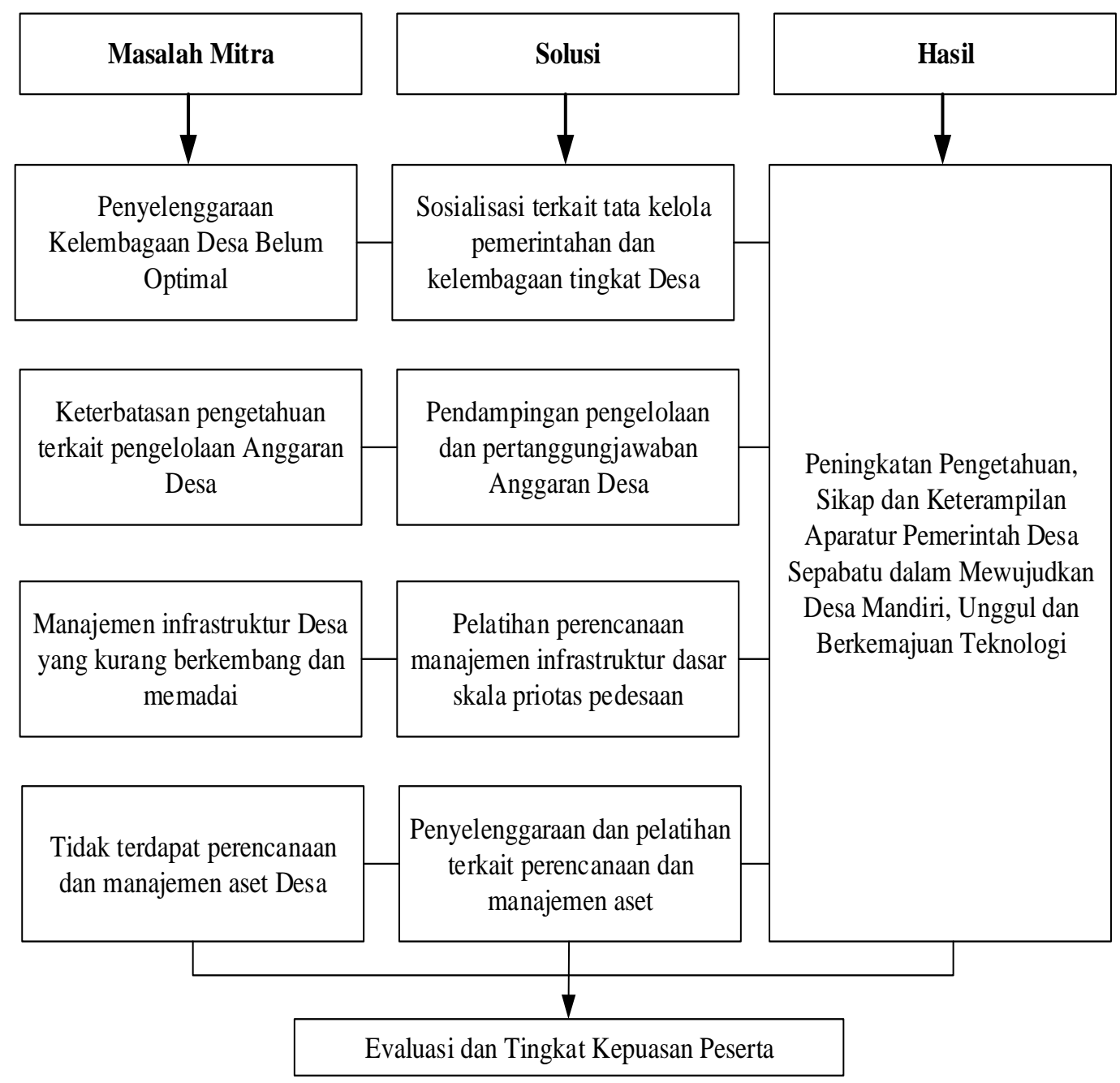

Figur1. Metode Pelaksanaan Pengabdian Masyarakat Desa Sepabatu

\section{HASIL DAN PEMBAHASAN}

Konsolidasi tim dan perencanaan awal kegiatan program pendampingan dilakukan dengan menyusun materi pelatihan dalam menjawab kebutuhan permasalahan mitra. Hasil penyusunan materi program diharapkan mampu membangun tata kelola pemerintahan desa yang berasaskan Good Governance dan Clean Governance. Aparatur desa difokuskan untuk dapat memahami tentang kelembagaan desa, pengelolaan keuangan desa serta aset desa dan infrastuktur desa. 
Tabel 1. Materi Program Pendampingan Peningkatan Kapasitas Aparatur Desa

\begin{tabular}{cl}
\hline \multicolumn{1}{c}{ Program } & \multicolumn{1}{c}{ Materi Pelatihan dan Pendampingan } \\
\hline \multirow{2}{*}{ (Dasar) } & Dasar pengelolaan anggaran dana desa \\
\cline { 2 - 2 } & Peraturan perundang-undangan tentang dana desa \\
\cline { 2 - 2 } & Kelembagaan dan manajemen pengelolaan aset desa \\
\cline { 2 - 2 } & Dasar pelaporan anggaran dana desa \\
\cline { 2 - 2 } (Pengemik pengelolaan dana desa dan manajemen aset desa \\
\hline (Pengembangan) & Perencanaan dan manajemen pengelolaan infrastruktur desa \\
\hline (Aplikasi) & Penganajemen keuangan dana desa \\
\hline (Evaluasi) & Evaluasi hasil pelatihan penggunaan dana desa \\
\hline
\end{tabular}

Pelaksanaan kegiatan dilangsungkan dengan melakukan konsolidasi bersama tim pengajar yang berkompeten pada masing-masing bidang sesuai dengan materi pelatihan yang telah disusun pada tahapan konsolidasi dan perencanaan. Pelaksanaan pendampingan di lapangan dilakukan dalam waktu yang telah ditetapkan, dan berlokasi di kantor Desa Sepabatu selaku mitra pengabdian masyarakat.

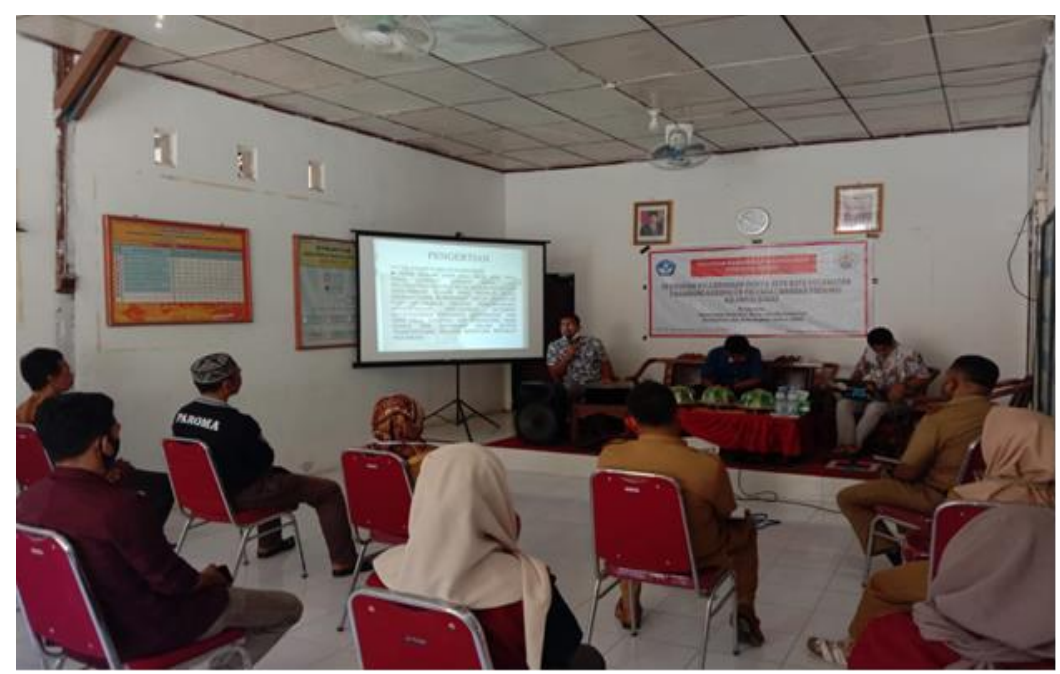

Figur 2. Dokumentasi Kegiatan Pendampingan Aparatur Desa Sepabatu

Tahapan evaluasi yaitu melakukan penyusunan capaian indikator yang akan berikan kepada peserta untuk melihat peningkatan perubahan pengetahuan setelah mengikuti kegiatan pendampingan. Dalam proses menentukan capaian indikator yang dilakukan yaitu dengan 
melakukan penilaian langsung di lapangan terhadap aparatur desa dalam menjalankan proses pemerintahan dan pengelolaan desa. Setiap aparatur desa memiliki tupoksi dalam menjalankan peran dan fungsinya sehingga sepatutnya perlu dilakukan pengembangan dalam menjadikan setiap kinerjanya menjadi lebih terarah dan meningkat dengan signifikan.

Tabel 2. Indikator Kegiatan Pendampingan Pengabdian Masyakat Desa Sepabatu

\begin{tabular}{cl}
\hline \multicolumn{1}{c}{ Cakupan } & \multicolumn{1}{c}{ Indikator } \\
\hline & $\begin{array}{l}\text { Aparatur pemerintahan desa dapat mengetahui dan memahami } \\
\text { maksud dan tujuan dari kelembagaan desa }\end{array}$ \\
\cline { 2 - 3 } Pengetahuan & $\begin{array}{l}\text { Aparatur pemerintah desa dapat mengetahui dan memahami } \\
\text { teknis pengelolaan dan pelaporan Anggaran Dana Desa }\end{array}$ \\
\cline { 2 - 3 } & $\begin{array}{l}\text { Aparatur pemerintah desa dapat memahami pengelolaan aset } \\
\text { desa menuju desa mandiri }\end{array}$ \\
\cline { 2 - 3 } Sikap & $\begin{array}{l}\text { Aparatur pemerintahan desa dapat mengetahui dan memahami } \\
\text { pengelolaan dana desa dan manajemen infrastruktur desa }\end{array}$ \\
& $\begin{array}{l}\text { Aparatur pemerintahan desa } \\
\text { menilai, mengorganisir, menanggapi pentingnya kelembagaan } \\
\text { desa, pengelolaan dana desa dan manajemen infrastruktur }\end{array}$ \\
\hline \multirow{2}{*}{ Keterampilan } & $\begin{array}{l}\text { Aparatur pemerintahan desa mengetahui dan memahami } \\
\text { implementasi dari kelembagaan desa, pengelolaan keuangan } \\
\text { yang berbasis prioritas dan manajemen infrastruktur yang } \\
\text { sesuai dengan kebutuhan/kondisi desa }\end{array}$ \\
\hline
\end{tabular}

Melihat Tabel 2 di atas, kegiatan yang menjadi indikator yang akan dijustifikasi dalam kegiatan peningkatan kapasitas aparatur Desa Sepabatu. Hasil penyusunan indikator ini merupakan target dalam mengukur efektivitas pelaksanaan pendampingan terkait permasalahan mitra. Cakupan yang dievaluasi yaitu pengetahuan, sikap dan keterampilan yang kedepaannya akan mendukung terciptanya urusan penyelenggaraan tata kelola pemerintahan desa yang lebih baik dan berasaskan Good Governance serta Clean Governance. Pengukuran dilakukan cara memberikan ujian tertulis dan metode tanya jawab secara langsung kepada peserta yang mengkuti kegiatan pendampingan. Hasil pemantauan evaluasi dari indikator-indikator yang ada disajikan dalam bentuk grafik yang dapat dilihat pada Figur 3. 


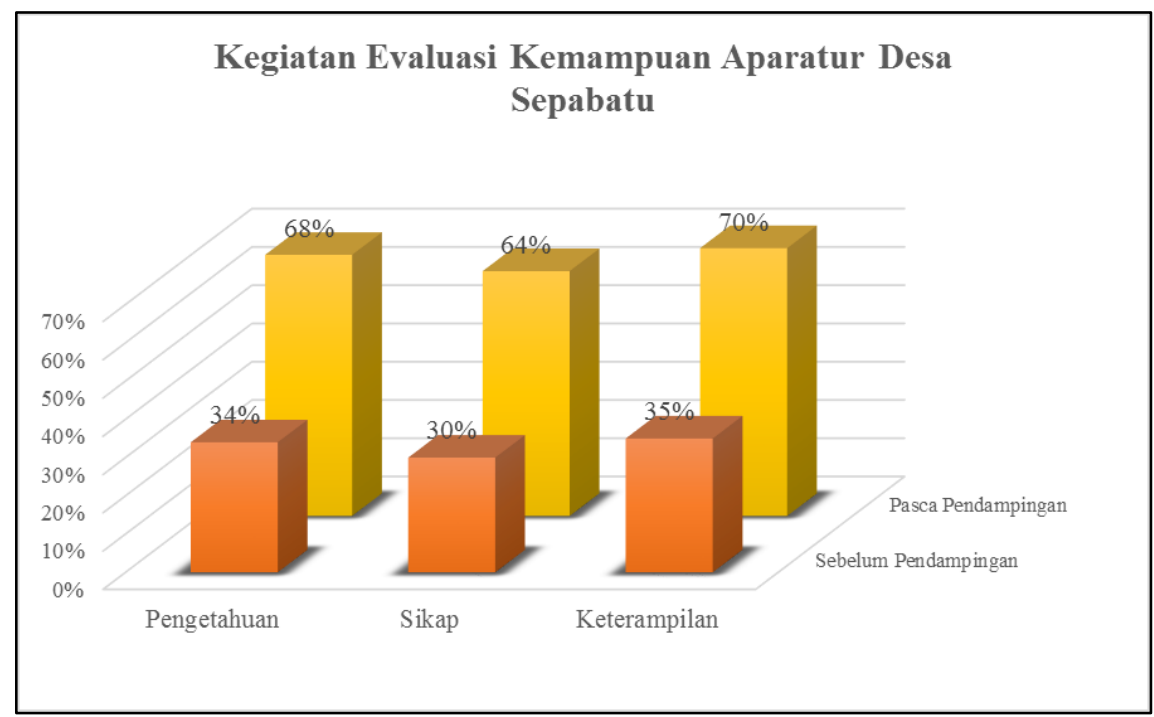

Figur 3. Hasil Evaluasi Kegiatan Pendampingan Aparatur Desa

Penilaian yang dilakukan di awal (pre-test) didapatkan hasil yang menunjukkan kemampuan eksisting dari para aparatur desa rata-rata sebesar 33,5\% terkait indikatorindikator yang menjadi acuan dalam penyelenggaraan pemerintahan di tingkat desa. Hal ini mengindikasikan bahwa kemampuan para aparatur desa masih minim dan penyelenggaraan yang ada hanya berdasarkan acuan-acuan yang bersumber dari pengurus-pengurus sebelumnya, tanpa ada improvisasi menyesuaikan perkembangan global saat ini. Di sisi lain juga hal ini mengindikasikan beberapa aparatur masih menganggap pelayanan cukup seperlunya dan tidak mengedepankan pelayanan yang berbasiskan pada kebutuhan masyarakat.

Pada proses selanjutnya setelah melakukan proses pendamping dan dilakukan penilaian kembali (post-test) didapatkan hasil yang menjadi lebih baik dari sebelumnya terdapat peningkatan sebesar $34,33 \%$ sehingga hasil pemahaman dan kemampuan menjadi rata-rata $67,42 \%$. Ini memperlihatkan efektivitas dari proses pendampingan selama proses kegiatan memberikan hasil yang signifikan dalam penguatan kapasitas aparatur pemerintahan Desa Sepabatu. Peningkatan pemahaman di bidang pengelolaan keuangan, aplikasi berbasis internet, pemahaman pelaksanaan teknis perundang-undangan menjadi lebih meningkat sehingga penyelenggaran pemerintahan menjadi lebih tepat dan inovatif. Hasil tersebut akan terus meningkat kedepan dengan terus melakukan pendampingan yang berkelanjutan.

Proses penilaian selanjutnya dilakukan dengan mengukur satisfaction index yang dilakukan kepada para aparatur pemerintahan Desa Sepabatu dengan melakukan survei kepuasan dengan menggunakan kuisioner untuk melihat seberapa jauh tingkat kepuasan 
dalam menjalani program penguatan yang diberikan selama waktu pengabdian. Aparatur diminta mengisi kuisioner dengan menjawab berbagai pertanyaan dengan ukuran skala tertentu dan alasan memilih jawaban tersebut, hal ini akan memperlihatkan pengukuran nilai kepuasan yang dapat dikuantifikasikan dengan skala tertentu. Alasan yang diberikan dikategorikan untuk mencegah terjadinya jawaban yang tidak rasional. Hasil dari penilaian pengukuran satisfaction index dapat dilihat pada gambar 4 dibawah ini.

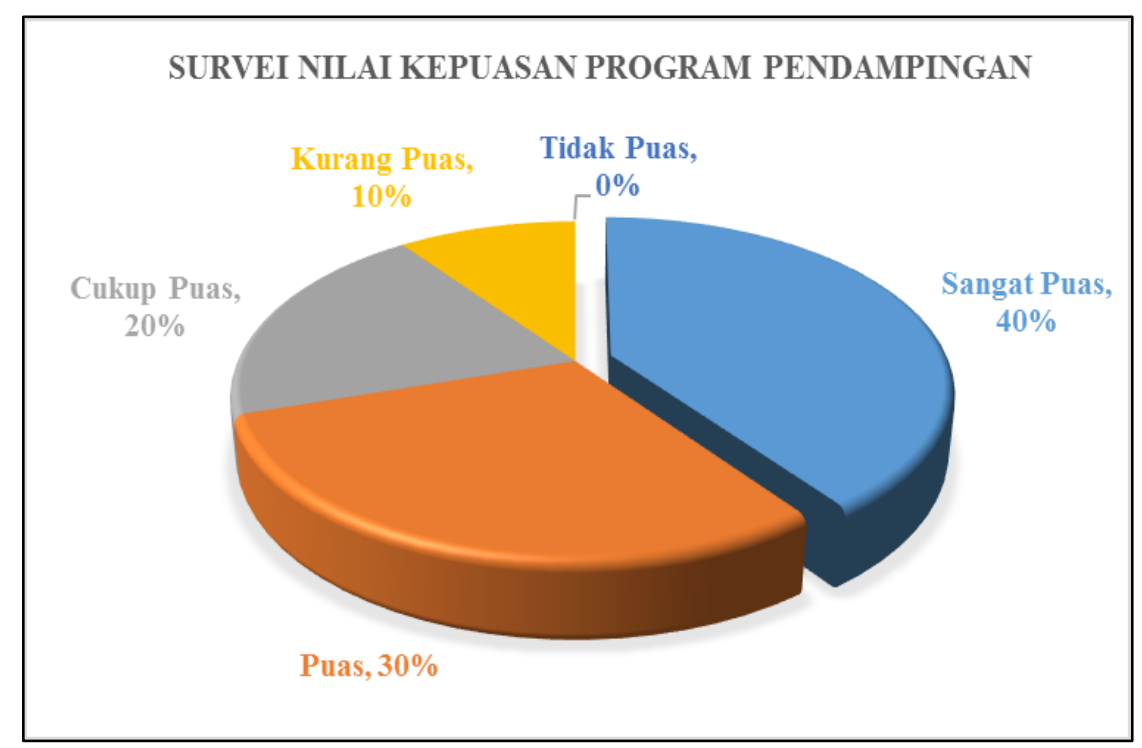

Figur 4. Hasil Survey Kegiatan Pendampingan Aparatur Desa

Penilaian dari hasil survei kepuasan penyelenggaraan program pendampingan yang dilakukan dihasilkan seperti pada Figur 4. Penilaian terhadap aparatur pemerintah Desa Sepabatu memperlihatkan adanya indeks sangat puas sebesar $40 \%$ dalam mengikuti proses pelatihan dan pendampingan yang dilakukan oleh tim, kemudian pada posisi $30 \%$ merasa puas dengan adanya program ini. Di sisi lain terdapat persepsi cukup puas $20 \%$ dan kurang puas $10 \%$. Hal ini dikaji lebih lanjut dikarenakan sebagian merasa waktu melakukan program tersebut kurang panjang, selain dari sisi waktu adalah masih ada kurangnya keefektifan dalam memberikan materi pelatihan terutama pada usia yang relatif lanjut ( $\geq 45$ tahun).

Perbaikan serta peningkatan aparatur desa yang dilakukan dalam kegiatan pemberdayaan masyarakat terlihat mampu memberikan efek yang baik dalam membuat pemerintah desa mampu mewujudkan tata kelola pemerintahan yang akuntabilitas, transparansi, profesional dan patuh terhadap peraturan perundang-undangan yang berlaku. Upaya peningkatan kapasitas aparatur desa perlu dilakukan secara rutin dan menyeluruh. Dalam ketidakoptimalan yang terkait kemampuan aparatur desa yang didapatkan bahwa 
penyelenggaran pemerintahan desa yang tidak mampu membina komunikasi yang baik antara aparatur desa dan masyarakat. Hal ini perlu dilakukan keterlibatan seluruh pihak dalam menyampaikan informasi dan pendelegasian wewenang sesuai dengan tugas dan fungsi pokoknya.

\section{KESIMPULAN DAN SARAN}

Dari kegiatan yang telah dilaksanakan, dapat disimpulkan beberapa hal yaitu tingkat keberhasilan pencapaian dengan menggunakan indikator perubahan perilaku untuk kegiatan pelatihan kelembagaan desa, pengelolaan keuangan desa, manajemen aset dan infrastruktur desa adalah rata-rata sebesar 67,83\%. Terdapat peningkatan yang sebesar 34,33\% dari kondisi awal rata-rata 33,50\% sebelum diadakannya program pelatihan dan pendampingan ini. Hasil dari pengukuran satisfaction index memperlihatkan $30-40 \%$ sangat puas dengan adanya program yang dijalankan ini sehingga perlu dilaksanakan secara berkelanjutan kedepannya.

Aparatur Pemerintahan Desa Sepabatu sebagai mitra pengabdian masyarakat memiliki respons dan antusias yang sangat besar terutama dalam proses pelatihan walaupun dengan segala keterbatasan yang dimiliki. Kegiatan pengabdian masyarakat antara tim pengabdian bersama masyarakat di Sepabatu melalui kegiatan pelatihan penguatan kapasitas aparatur di bidang kelembagaan desa, pengelolaan keuangan desa, manajemen aset dan pengelolaan infrastruktur desa berjalan sesuai dengan rencana dan target yang telah ditetapkan. Disisi lain yang menjadi tantangan dalam hasil selama melakukan program ini adalah manajemen pelaksanaan dari sisi waktu, kurangnya disiplin dari para peserta menjadikan kegiatan berlangsung tidak efektif. Faktor pemerataan latar belakang pendidikan yang dimiliki oleh para aparatur desa Sepabatu menjadi kendala untuk menyeragamkan ilmu dan materi yang harus diberikan selama program pelatihan dan pendampingan.

\section{UCAPAN TERIMA KASIH}

Kegiatan ini terlaksana dengan menggunakan dana yang bersumber dari Daftar Isian Pelaksanaan Anggaran (DIPA) Direktorat Riset dan Pengabdian Masyarakat, Kementerian Riset dan Teknologi/ Badan Riset dan Inovasi Nasional Tahun Anggaran 2019. Selain itu, Pihak Universitas Sulawesi Barat dalam hal ini Lembaga Penelitian dan Pengabdian 
Masyarakat (LPPM) sebagai pihak yang memberikan bantuan dari segi teknis dan administrasi kegiatan. Kemudian, pihak aparatur Desa Sepabatu yang menjadi mitra dalam terlaksananya kegiatan ini, serta pihak lain yang turut serta dalam menjadikan kegiatan ini berjalan dengan lancar dan sesuai dengan target yang direncanakan.

\section{REFERENSI}

Arsjad, M. F. (2018). Peranan Aparat Desa dalam Pelaksanaan Administrasi Pemerintahan Desa di Desa Karyamukti Kecamatan Mootilango Kabupaten Gorontalo. Gorontalo Journal of Public Administration Studies, 1(1), 16-32

Astuti, T. P., dan Yulianto. (2016). Good Governance Pengelolaan Keuangan Desa Menyongsong Berlakunya Undang-Undang No . 6 Tahun 2014. Berkala Akuntansi Dan Keuangan Indonesia, 1(6), 1-14.

Badan Pusat Statistik. (2020). Kecamatan Tinambung Dalam Angka 2020. In BPS.

Hasibuan, S., Rasal, A., dan Ashari, E. (2020). Pendampingan dalam Mewujudkan Budaya Tertib Arsip Informasi KTP dan KK di Kantor Kelurahan Pulau Abang, Provinsi Kepulauan Riau Assistance in Supporting Well Culture of KTP and KK information archiving at Pulau Abang Sub-district office, Kepulauan Riau. Minda Baharu, 4(1), 20-31.

Nugroho, S., Wijaya, A. F., dan Said, M. (2016). Pengembangan Kapasitas Aparatur Pemerintahan Desa Dalam Upaya Mewujudkan Good Governance (Studi Pada Balai Besar Pemberdayaan Masyarakat dan Desa di Malang). Jurnal Administrasi Publik, 1(5), 1010-1016.

Peraturan Pemerintah Nomor 60 Tahun 2014 Tentang Dana Desa Yang Bersumber Dari Anggaran Pendapatan Dan Belanja Negara.

Peraturan Menteri Desa, Pembangunan Daerah Tertinggal, Dan Transimgrasi Nomor 5 Tahun 2015 Tentang Penetapan Prioritas Penggunaan Dana Desa Tahun 2015.

Salahudin, S. (2016). Model Penguatan Kapasitas Pemerintah Desa dalam Menjalankan Fungsi Pemerintahan Berbasis Electronic Government (E-Goverment) Menuju Pembangunan Desa Berdaya Saing (Salahuddin (ed.); 1st ed., Issue September). Direktorat Penelitian dan Pengabdian kepada Masyarakat (DPPM).

Sidik, F. (2017). Pelaksanaan Pemberdayaan Aparatur Pemerintah Desa Dalam Meningkatkan Kapasitas Penyelenggaraan Pemerintahan Desa Di Desa Kurnia Bakti Kecamatan Ciawi Kabupaten Tasikmalaya. Moderat: Jurnal Ilmiah Ilmu Pemerintahan, 3(1), 133-149.

Sulandra, I. M., dan Mudarya, I. N. (2018). Kemampuan Aparat Desa dalam Pelaksanaan Tugas Administrasi Pemerintahan Desa. Locus Majalah Ilmiah FISIP, 10(1), 91-108.

Syafingi, H. M., Dewi, D. A. S., dan Aji, A. B. (2018). Paradigma Aparatur Desa dalam Penggunaan Dana Desa untuk Pemberdayaan Masyarakat. Pandecta: Research Law Journal, 13(2), 139-149. 
Taufiq, O., Yuliani, D., dan Hermawandi, D. (2019). Tata Kelola Pemerintah Desa Berbasis E-Government Menuju Good Governance. Dinamika: Jurnal Ilmiah Ilmu Administrasi Negara, 6(1), 145-152.

Undang-Undang Nomor 6 Tahun 2014 Tentang Desa.

Zamora, R., dan Nurhayati. (2019). Pendampingan Dan Pelatihan Kewirausahaan Masyarakat Nelayan Di Tanjung Gundap. Minda Baharu, 3(2), 75-83. 